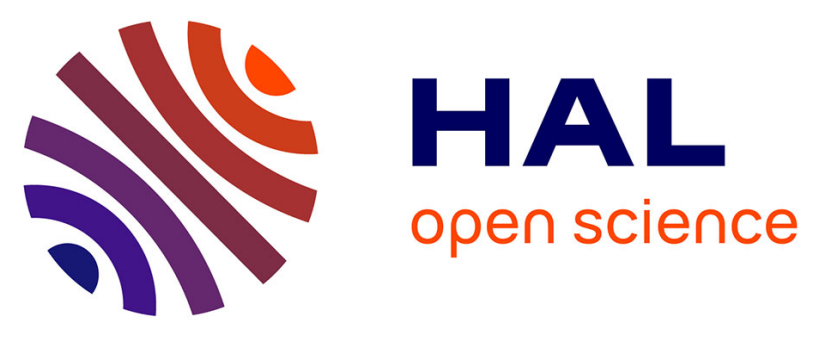

\title{
Impact of Antiretroviral Drugs on Fracture Risk in HIV-Infected Individuals: A Case-Control Study Nested Within the French Hospital Database on HIV (FHDH-ANRS CO4)
}

Dominique Costagliola, Valérie Potard, Sylvie Lang, Sophie Abgrall, Claudine Duvivier, Hugues Fischer, Véronique Joly, Jean-Marc Lacombe, Marc-Antoine Valantin, Murielle Mary-Krause, et al.

\section{- To cite this version:}

Dominique Costagliola, Valérie Potard, Sylvie Lang, Sophie Abgrall, Claudine Duvivier, et al.. Impact of Antiretroviral Drugs on Fracture Risk in HIV-Infected Individuals: A Case-Control Study Nested Within the French Hospital Database on HIV (FHDH-ANRS CO4). Journal of Acquired Immune Deficiency Syndromes - JAIDS, 2019, 80 (2), pp.214-223. 10.1097/QAI.0000000000001903 . hal02291243

\section{HAL Id: hal-02291243 \\ https://hal.sorbonne-universite.fr/hal-02291243}

Submitted on 18 Sep 2019

HAL is a multi-disciplinary open access archive for the deposit and dissemination of scientific research documents, whether they are published or not. The documents may come from teaching and research institutions in France or abroad, or from public or private research centers.
L'archive ouverte pluridisciplinaire HAL, est destinée au dépôt et à la diffusion de documents scientifiques de niveau recherche, publiés ou non, émanant des établissements d'enseignement et de recherche français ou étrangers, des laboratoires publics ou privés. 


\section{nested within the French Hospital Database on HIV (FHDH-ANRS CO4)}

Dominique Costagliola ${ }^{1}$, Valérie Potard ${ }^{1,7}$, Sylvie Lang ${ }^{1,7,8}$, Sophie Abgrall ${ }^{1,6}$, Claudine Duvivier ${ }^{2}$, Hugues Fischer ${ }^{3}$, Véronique Joly ${ }^{4}$, Jean-Marc Lacombe ${ }^{1,7}$, Marc-Antoine Valantin ${ }^{1,5}$, Murielle MaryKrause $^{1}$, Sylvie Rozenberg ${ }^{5}$ on behalf of FHDH ANRS CO4

1 Sorbonne Université, INSERM, Institut Pierre Louis d’Epidémiologie et de Santé Publique (IPLESP), Paris, France

2 APHP, Hôpital Necker-Enfants Malades, Service de Maladies Infectieuses et Tropicales, Centre d'infectiologie Necker-Pasteur, IHU Imagine, Paris, France

3 TRT5, Paris, France

4 APHP, Hopital Bichat, Paris, France

5 APHP, Hôpital Pitié-Salpêtrière, Paris, France

6 APHP, Hopital Antoine Béclère, Clamart, France

7 Inserm Transfert, F-75013 Paris, France

8 Sorbonne Université, APHP, Hôpital Saint-Antoine, Hôpitaux de l'Est Parisien, Service de Cardiologie, F75012 Paris, France;

Corresponding author: Dominique Costagliola

E-mail address: dominique.costagliola@Iplesp.upmc.fr

Inserm UMR_S 1136, 56 Bd Vincent Auriol, CS 81393, 75646 Paris Cedex 13, France.

Phone: +33 (0)1 $42164282 \quad$ Fax: +33 (0)1 42164261

Alternate corresponding author: Valérie Potard

E-mail address: valerie.potard@Iplesp.upmc.fr

Inserm UMR_S 1136, 56 Bd Vincent Auriol, CS 81393, 75646 Paris Cedex 13, France.

Phone: +33 (0)142164270 Fax: +33(0)1 42164267

\section{Conflicts of Interest and Source of Funding}

FHDH is supported by France REcherche Nord \& Sud Sida-hiv Hépatites (ANRS), Institut National de la Santé et de la Recherche Médicale (INSERM) and the French Ministry of Health.

This work was funded by France REcherche Nord \& Sud Sida-hiv Hépatites (ANRS) and the Agence Nationale de Sécurité du médicament et des produits de santé (ANSM). After approval of the protocol, ANRS and ANSM had no role in the conduct of the study; in the collection, analysis or interpretation of the data; or in the preparation, review or approval of the manuscript.

VP, JML, MMK reported no conflict of interest; DC was a member of the French Gilead HIV board from 2011 to 2015. In the past 3 years she gave lectures for Janssen-Cilag, and MSD and received travel/accommodations/meeting expenses from ViiV. She conducted post-marketing studies for Janssen-Cilag, MSD, and ViiV. She was a consultant for Innavirvax and Merck Switzerland. SL has received travel grants from Boehringer Ingelheim. SA is a member of the Janssen-Cilag HIV board. In the past 3 years she received travel/accommodations/meeting expenses from Gilead, ViiV, Janssen-Cilag. CD has received travel grants, honoraria or study grants from various pharmaceutical companies, including Bristol-Myers Squibb, Gilead Sciences, Janssen, Merck and ViiV Healthcare. SR has received honoraria in 2016 from Gilead for a meeting.

Keywords: Fracture; bone mineral density; antiretroviral drugs; tenofovir; protease inhibitors

Running title: Impact of ARVs on fracture risk

Running title: 32 characters (40 characters max)

Abstract: 250 words (250 words max)

Text: 3365 words (3500 words max)

1 figure, 3 tables, 2 supplementary tables

This work was presented at the 9th IAS Conference on HIV Science , 23-26 July 2017, Paris, France, WEAB0103. 


\section{Abstract}

Background: HIV-infected patients have lower bone mineral density and a higher incidence of fractures than the general population of the same age and sex. To assess the impact of antiretroviral drugs (ARV) exposure on the risk of osteoporotic fractures, we conducted a nested case-control study.

Methods: Cases were individuals enrolled while ARV-naive, with a first prospectively recorded fracture between 2000 and 2010. Controls were randomly selected after matching for sex, age ( $\pm 3 y e a r s$ ), period of HIV diagnosis $(<1997 / \geq 1997)$ and clinical centre. The risk of fracture was analysed with conditional logistic regression models, using different ways to model ARV exposure. All exposure variables and potential confounders were included in multivariable models.

Results: Among 861 reviewed cases, 261 fractures were osteoporotic and 254 of cases were matched to at least one control (376 controls). The median year of fracture diagnosis was 2007 (IQR 2004-2009): $49 \%$ of patients had been exposed to tenofovir disoproxil fumarate (TDF) and $82 \%$ to protease inhibitors (PIs).

After taking into account the transmission group, AIDS status, geographic origin, BMI, current smoking status, alcohol consumption, exposure to systemic glucocorticoids, and the period of enrolment, there was no association between the risk of fracture and exposure to TDF (OR for cumulative exposure: 1.04 [0.86-1.27], similar results for ever-exposed subjects), to NRTIs, or to PIs (OR for cumulative PI exposure: 1.02 [0.92-1.12]).

Conclusion: We found no evidence of an excess risk of fracture following exposure to TDF or PIs. This has important implications for the debate concerning tenofovir alafenamide versus generic TDF. 


\section{Introduction}

People living with HIV (PLHIV) have a lower bone mineral density (BMD) [1] and a higher incidence of fractures than the general population of the same age and sex [2-7]. Data from randomized trials in antiretroviral treatment (ARV) naive patients show that BMD declines after ARV initiation [8,9], especially with tenofovir disoproxil fumarate (TDF) compared to other nucleoside reverse transcriptase inhibitors (NRTIs) both at the lumbar spine and the hip [10,11]. The decline was also greater with protease inhibitors (PIs) than with non nucleoside reverse transcriptase inhibitors (NNRTIs) at the lumbar spine [10,12]. The data concerning PIs might be artefactual being linked to an increase in visceral fat. A significant gain in fat mass correlating with a sharp drop in BMD has been observed during PI exposure [13]. Simulated increases in body fat reduced the mean Dual-energy X-ray absorptiometry (DXA) spine BMD but did not affect the mean DXA hip BMD, a finding that might explain the trial results [14]. In trials of pre-exposure prophylaxis (PrEP), in HIV-uninfected individuals, TDF was associated with a small decline in BMD $[15,16]$. In the SMART trial, ARV discontinuation was followed by an increase in BMD [17]. Ten studies (see supplementary table 1 ) have examined links between specific ARV and the risk of fracture [5,7,18-25]. They variously considered fractures, fractures at osteoporotic sites (or both), or low-energy fractures. They also differed in the confounders they took into account. In particular few considered classical risk factors for osteoporotic fractures such as the body mass index (BMI), ethnic origin, current smoking status, daily alcohol consumption exceeding two units, a family history of hip fracture, systemic glucocorticoids, rheumatoid arthritis, and menopausal status [26]. Few of these studies showed an association between an increased risk of fracture and exposure to TDF or to PIs (respectively $1 / 7$ and $1 / 6$ ), or of fractures at osteoporotic sites (respectively $2 / 6$ and 2/3). In one of the study [5] showing a statistical association between ongoing PI exposure and an increased risk of fracture, the authors considered that the link was not causal. The purpose of the present study was to assess the possible impact of ARV on the risk of low-energy fractures at potential osteoporotic sites focusing on PIs and TDF. 


\section{Methods}

\section{The French Hospital Database on HIV (FHDH-ANRS CO4)}

The FHDH is a hospital-based open multicentre cohort in which inclusions have been ongoing since 1989 [27]. Individuals are eligible if they have documented HIV-1 or HIV-2 infection and give their written informed consent to participate. Data are collected prospectively by trained research assistants on standardized forms, which include demographic characteristics, the date and type of clinical events recorded according to the International Disease Classification ART and biological markers. The FHDH project was approved by the French data protection authority (Commission National de l’Informatique et des Libertés on 27 November 1991, Journal Officiel, 17 January 1992).

\section{Study design}

The protocol, including a detailed statistical analysis plan, was written at the time of submission of the project to the French medicines agency (Agence Nationale de Sécurité du médicament et des produits de santé (ANSM)) and to France REcherche Nord \& Sud Sida-hiv Hépatites (ANRS).

We conducted a case-control study nested in the FHDH and focusing on HIV-1 infected individuals who were enrolled in the FHDH while ARV-naive. We chose this approach because of the timevarying nature of ARV use, the large size of the cohort, and the long duration of follow-up [28]. Moreover, compared with a full cohort approach with a survival analysis using time-dependent variables, a nested case-control analysis provides estimates of odds ratios (ORs) from conditional logistic regression models that are unbiased estimates of relative risk (RR) [29].

\section{Case definition}

Cases were individuals enrolled in the FHDH while ARV-naive and who had a first prospectively reported low-energy fracture at a potential site of osteoporotic fracture between January 2000 and December 2010. Individuals who were selected as controls but for whom a fracture report was found 
in their medical records when extracting the data were also considered as cases. The potential osteoporotic sites were the vertebrae, hip, wrist, upper humerus, lower femur, upper tibia, and simultaneous fracture of 3 or more ribs. A low-energy fracture was defined as a fracture sustained after mild trauma such as a fall from standing height.

\section{Selection of controls}

Controls were individuals enrolled in the FHDH while ARV-naive and with no history of fracture. They were randomly selected with the incidence density sampling method [30], after individual matching for sex, age ( \pm 3 years), period of HIV diagnosis $(<1997 / \geq 1997)$, being under follow-up at the date of fracture in the corresponding case ( \pm 3 months) and, if possible, the clinical centre.

\section{Potential confounders}

It was important to take into account pre-existing risk factors for fractures that might have influenced the choice of ARV during the study period. The following traditional risk factors were explored: geographic origin (sub-Saharan Africa/other), BMI (underweight $(<18.5) /$ normal $(18.5 \leq \mathrm{BMI} \leq 25) /$ overweight (>25)), smoking status (no/past/current), alcohol consumption above two glasses per day (no/yes), family history of hip fracture (no/yes), prior exposure to systemic glucocorticoids (no/yes) and menopausal status for women (no/yes). We also studied the potential effect of the following HIV-related variables on the risk of fracture: period of enrolment in the FHDH $(\leq 1996 / 1997$ 2001/2002-2010), transmission group (men who have sex with men (MSM)/other), period of ARV initiation (Naive/<1997/1997-2001/2002-2010), AIDS status, CD4 T-cell nadir, and anti-hepatitis C virus antibody status ( $\mathrm{HCV}$ Ab-/HCV $\mathrm{Ab}+$ ) before the date of fracture in the cases. In addition, we considered the CD4 T-cell count, CD8 T-cell count, CD4 to CD8 T-cell ratio and viral load (VL) measured within 6 months of the date of fracture in the cases. Finally, we collected available data on osteoporosis which could be on the causal pathway between ARV exposure and the risk of fracture and chronic kidney disease (dialysis or estimated glomerular filtration rate (eGFR) using the CKDEPI equation from creatinine level $<60 \mathrm{~mL} / \mathrm{min} / 1.73 \mathrm{~m}^{2}$ (no/yes)) which may lie on the causal 
pathway between TDF exposure and the risk of fracture. These last 2 variables were only to be used in sensitivity analyses if a significant association was found between exposure to any ARV and the risk of fracture.

\section{Data collection}

The date of fracture diagnosis, sex, age, geographic origin, and HIV parameters were extracted from the FHDH and validated in the medical records by trained medical assistants using a predefined case report form. We also collected the site and circumstances of the fracture, and potential confounders described above from the medical records. In addition, we used self administered questionnaire filled by the study participants to collect the date(s), site(s) and circumstance(s) of antecedent if any and referent fracture(s), smoking status, alcohol consumption above two units per day, a family history of hip fracture, systemic glucocorticoids, menopausal status, known osteoporosis, and dialysis. When data were recorded both in the medical records and in the questionnaire, we used the data from the questionnaire. When a value was missing both from the medical records and from the questionnaire, we used the value recorded in the FHDH if available.

\section{Statistical analysis}

Conditional logistic regression models were used to quantify the relation between exposure to individual antiretroviral drugs and the risk of fracture. Exposure to each drug was considered as the cumulative duration of exposure (model 1), or as “ever exposed” (yes/no) (model 2). In a $3^{\text {rd }}$ model, the exposure variable for each antiretroviral drug was chosen according to the lowest values of Akaike's information criterion (AIC) in univariable models of the risk of fracture. In sensitivity analyses, exposure to each antiretroviral drug was modelled by a 3-category variable: never exposed, exposed for less than 2 years, and exposed for 2 years or more. ARV for which of less than 10\% of controls were exposed was taken into account in the analyses, but the results are not reported. We also explored exposure to all PIs (darunavir (DRV), atazanavir (ATV), fosamprenavir/amprenavir 
(FPV/AMP), indinavir (IDV), lopinavir (LPV), nelfinavir (NFV), ritonavir (RTV), saquinavir (SQV)) and in separate models, exposure to first-generation PIs (all PIs except ATV and DRV).

Characteristics of the cases and controls were compared by using univariable conditional logistic regression. Known risk factors for fracture, except for menopausal status, were included in the multivariable models if they were present in at least 5\% of individuals. Regarding factors related to HIV infection, these were included in the multivariable models if in the corresponding univariable conditional logistic regression model, the P value was below 0.10. For VL, CD4, the CD4 nadir, CD8, and CD4/CD8. The choice between continuous and categorical classification was based on the lowest AIC value in the corresponding univariable conditional logistic regression model.

All values missing for fewer than $50 \%$ of individuals were replaced by using a multiple imputation method, missing values being randomly sampled from their predicted distributions [29]. Ten sets of imputations were used to create 10 complete datasets. All 10 datasets were analyzed and combined with Rubin’s rules. SAS software (v9.4; SAS Institute Inc, Cary, NC, USA) was used for all statistical analyses.

\section{Results}

\section{Baseline characteristics of participants}

The study flow chart is shown in figure 1. Among the 861 reviewed fractures, 261 low-energy fractures at a potential osteoporotic site were validated, and 254 of the patients concerned were matched with at least one control (376 controls). With a total of 254 cases and 376 controls, the odds ratios that could be detected with $80 \%$ power and a 5\% type-one error were above 1.6 to 2.0 for exposure in the control group ranging from $50 \%$ to $10 \%$. There were 285 self administered questionnaires completed of which 101 (41\%) for the cases and 184 (49\%) for the controls. Two hundred (78.7\%) of the 254 cases had had only one fracture, 37 (14.6\%) 2 fractures, 11 (4.3\%) 3 fractures and 6 (2.4\%) 4 fractures. There were 53 spine, 69 hip, 51 wrist, 30 humerus upper end, 11 femur lower end, 14 tibia upper end, 6 simultaneous 3-rib and 20 other fractures. The median year of 
fracture diagnosis was 2007 [interquartile range (IQR), 2004-2009]. Characteristics of the cases and controls are shown in table 1 . The rate of missing values was lower than $50 \%$ for all potential confounders: $15 \%$ for BMI, 7\% for smoking status, $14 \%$ for alcohol consumption, 38\% for a family history of hip fracture, $16 \%$ for prior systemic glucocorticoid exposure, $13 \%$ for chronic kidney disease, $1 \%$ for the CD4 nadir, $1 \%$ for CD4, $6 \%$ for CD8 and $2 \%$ for VL. In the case population, median age was 49 years, $67 \%$ of patients were men, and $71 \%$ were diagnosed with HIV infection before 1997. Their median CD4 cell count was 436/ $\mathrm{mm}^{3}$ [IQR, 293-592], their nadir CD4 cell count was $172 / \mathrm{mm}^{3}$ [IQR, 75-298], and $65 \%$ of them had VL $<50$ copies/mL. The corresponding values in controls were not significantly different. The proportion of individuals with AIDS was higher among the cases than the controls (31\% versus 20\%). Regarding classical fracture risk factors, the cases were less likely to be of sub-Saharan origin and more likely to have low BMI, alcohol consumption $\geq$ 2 glasses/day, and to have been exposed to systemic glucocorticoids. Unsurprisingly, osteoporosis had been diagnosed in more cases than controls.

The proportions of ARV-exposed cases and controls and the mean duration of exposure to individual ARVs are shown in table 2 . At the date of fracture diagnosis, $49 \%$ of cases had been exposed to TDF and $82 \%$ to PIs, for 2.5 and 4.3 years respectively.

Less than $10 \%$ of controls had been exposed to darunavir, T20, raltegravir or maraviroc. In model 3, ARV exposure was modelled as follows: ever exposed (yes/no) to any ARV except EFV, ATV, DRV, FPV/APV and emtricitabine (FTC), the latter five drugs being modelled with their cumulative duration of exposure. In addition to ARV exposure, the multivariable models were adjusted for the period of FHDH enrolment, the HIV transmission group, prior AIDS-defining events, geographic origin, BMI, smoking status, alcohol consumption, and prior systemic glucocorticoid exposure.

\section{Impact of ARV exposure on the risk of fracture}

Univariable models of ARV exposure are shown in table 2. Multivariable models 1, 2, and 3 with adjustment for all ARV exposure and for all ARV exposure plus confounders are shown in table 3. 
Models 1 and 3 had lower AIC values than model 2, whether they were adjusted for all ARVs alone or for ARVs and confounders.

\section{Impact of TDF and PIs}

In both the univariable and multivariable models, and regardless of how ARV exposure was modelled, no association was found between TDF and the risk of fracture: the OR was 1.21 (95\% confidence interval (CI): [0.61-2.39]) in the ever-exposed model adjusted for ARV plus confounders and similar results were obtained for cumulative exposure (OR: 1.04, 95\% CI [0.86-1.27]). Results were not changed after including existence of chronic kidney disease in the models (data not shown). Atazanavir was associated with an increased risk of fracture in univariable models using both cumulative exposure (OR: 1.32, 95\% CI [1.08-1.62]), and ever exposure (OR: 1.59, 95\% CI [1.012.51]). After accounting for other ARVs and confounding factors, we found no significant association in model 2 (OR: 1.89, 95\% CI [0.96-3.72]), while the association was significant in model 1 (OR: 1.52, 95\% CI [1.06-2.17]) and in model 3 (OR: 1.49, 95\% CI [1.04-2.13]). In sensitivity analyses (supplementary table 2), atazanavir exposure for more than 2 years was associated with an increased risk of fracture in the univariable model (OR: 2.40, 95\% CI [1.07-4.15]) but not after accounting for other ARVs and confounding factors (OR: 2.37, 95\% CI [0.78-7.23]). We also checked whether there was an interaction between TDF and ATV and found no significant interaction (p-value=0.56 in Model 2 adjusted for ARV and confounders). Other PIs showed no significant association with the risk of fracture in any of the 3 multivariable models. Finally, there was no significant association between the risk of fracture and exposure to either all PIs or only to all first-generation PIs.

\section{Impact of NRTI exposure}

Zidovudine (ZDV) was associated with an increased risk of fracture in the univariable model using ever exposure (OR: 1.58, 95\% CI [1.04-2.41]) but not cumulative exposure (OR: 1.01, 95\% CI [0.961.06]). After accounting for other ARVs and confounding factors, ZDV was not associated with an increased risk of fracture in the 3 models. Zalcitabine (DDC) was not associated with the risk of 
fracture in univariable models using either cumulative or ever exposure. After adjustment for ARV and confounders, cumulative exposure to DDC was associated with a lower risk of fracture in model 1 (OR: 0.66, 95\% CI [0.45-0.97]), contrary to ever exposure to DDC. In adjusted models of sensitivity analyses, DDC exposure for more than 2 years was associated with a lower fracture risk (OR: 0.19, 95\% CI [0.05-0.79]), while DDC exposure for less than 2 years was not associated with the risk of fracture. However, only $6 \%$ of controls and $2 \%$ of cases had been exposed to DDC for more than 2 years. No other association was found between NRTIs and the risk of fracture in any of the 3 models.

\section{Impact of NNRTI exposure}

Univariable models showed no association between cumulative exposure or ever exposure to efavirenz. After accounting for ARV and confounding factors, cumulative efavirenz exposure was associated with a lower risk of fracture in models 1 and 3, with respective ORs of 0.81 [0.69-0.96] and 0.82 [0.70-0.96] per year of exposure. In sensitivity analyses, exposure to efavirenz for either less than 2 years or more than 2 years was not associated with the risk of fracture. The proportion of individuals exposed to EFV for more than 2 years was small (15\%).

Univariable models, showed no association between cumulative exposure to nevirapine (NVP) whereas ever exposure to NVP was associated with an increased risk of fracture, with an OR of 1.93 [1.32-2.83]. After accounting for other ARVs and confounding factors, NVP exposure was associated with a higher risk of fracture only in model 2.

\section{Discussion}

We found no robust association between the risk of fracture in HIV-infected patients and exposure to antiretroviral drugs including to TDF and PIs. Some drugs, particularly EFV associated with a lower risk and ATV associated with a higher risk, were significantly associated to the fracture risk in some of the models we constructed, however, sensitivity analyses showed that these associations were not robust. 
We used several approaches to minimize biases including the choice of a case-control design nested within the FHDH cohort, use of controls matched for age and sex, which are two important risk factors for fracture [26], as well as the period of HIV diagnosis (which influences exposure to the different ARVs), and adjustment for both HIV-related parameters and classical fracture risk factors. These classical risk factors were associated with the risk of fracture in our study, supporting the reliability of our data. HCV coinfection was not taken into account in the multivariable models, because its prevalence was low (6\%). Adding the variable in the models did not change our results. Several published studies have shown an association between HCV coinfection and the risk of fracture in populations with a higher prevalence of HCV infection. We recognize that our study does not provide information on the most recent drugs such as darunavir, rilpivirine, raltegravir, dolutegravir or elvitegravir.

Only one previous study has linked TDF to an increased risk of all fractures [23]. The difference between the two analyses reported in this paper is surprising. If the impact of TDF on the risk of fracture is mediated by its effect on BMD, the hazard ratio (HR) should be larger when the analysis is restricted to osteoporotic fractures rather than all fractures. And even if the exact HR value for osteoporotic fractures was not reported, it does not appear to be the case when looking at the figures of this paper. This does not support a causal link of the reported association. In addition one study [19] concluded that there was a modestly increased osteoporotic fracture risk associated with an cumulative TDF exposure, however, the association was only significant when restriciting the analysis to participants enrolled after 1996. In the ACTG study A5202 [10], despite a significant impact of TDF on BMD compared to abacavir, there was no significant difference in the incidence of fractures. Finally, a study based on the proportional reporting ratios of fracture in the EudraVigilance database between 2001 and 2016 did not show a disproportionality for all fractures in patients treated with TDF, while the disproportionality observed for osteoporotic fractures was based on 13 cases only [25]. This may well be explained by difference in reporting rates in EudraVigilance when TDF is part of an antiretroviral regimen. All others studies (supplementary Table 1) did not report an 
association between exposure to TDF and the risk of fractures. Exposure to TDF may affect BMD but not necessarily the risk of fractures, as the decline in BMD occurs mainly during the first two years of treatment. Recent studies have shown no effect of TDF on BMD except during treatment initiation [31,32]. In addition, only 10 to $44 \%$ of the risk of fractures can be attributed to low BMD [33]. In our study, the selected fractures occurred years after ARV initiation and only 9.0\% of case patients started ARV with a TDF-containing combination.

Only three studies have shown an increased risk of fracture with some PI exposure [5,19, 20], but it was not necessarily causal in one study [5] and consisted only of a moderate, non significant increase in the risk of osteoporotic fracture in the study by Bedimo et al, where only exposure to lopinavir was significantly associated with the risk of fracture [19]. In the study by Mundy et al, while exposure to all PI was not associated with an increased risk of fracture; exposure to darunavir and to saquinavir were associated with an increased risk of fracture [20]. As in our study, PIs were not found to be associated with the fracture risk in the remaining studies [7,22-25]. This is not unexpected, as the observed decline in spine BMD after PI exposure [10,12] was recently suggested to be a measurement artifact: BMD measurement at lumbar spine is less accurate following weight gain [14].

\section{Conclusion}

We found no evidence of an excess risk of fracture following exposure to TDF or to PIs. It would be interesting to study this risk during a more recent period in order to include more individuals initiating ARV with a TDF. These results have important implications for the use of tenofovir alafenamide versus generic TDF. 


\section{Acknowledgments}

The authors are grateful to all FHDH participants and research assistants, without whom this work would not have been possible.

Members of FHDH-ANRS CO4 are listed at http://www.ccde.fr/main.php?main_file=fl1171464013-677.html. 


\section{References}

1. Brown TT, Qaqish RB. Antiretroviral therapy and the prevalence of osteopenia and osteoporosis: a meta-analytic review. AIDS 2006; 20: 2165-2174.

2. Triant VA, Brown TT, Lee H, Grinspoon SK. Fracture prevalence among human immunodeficiency virus (HIV)-infected versus non-HIV-infected patients in a large U.S. healthcare system. J Clin Endocrinol Metab 2008; 93: 3499-3504.

3. Güerri-Fernandez R, Vestergaard P, Carbonell C, et al. HIV Infection Is Strongly Associated With Hip Fracture Risk, Independently of Age, Gender, and Comorbidities:A Population-Based Cohort Study. J. Bone Miner. Res. 2013; 28: 1259-1263.

4. Prieto-Alhambra D, Güerri-Fernández R, De Vries F, et al. HIV Infection and Its Association With an Excess Risk of Clinical Fractures: A Nationwide Case-Control Study. JAIDS 2014; 66: 90-95.

5. Womack JA, Goulet JL, Gibert C, et al. Increased risk of fragility fractures among HIV-infected compared to uninfected male veterans. PloS One 2011; 6: e17217.

6. Young B, Dao CN, Buchacz K, Baker R, Brooks JT. Increased rates of bone fracture among HIVinfected persons in the HIV Outpatient Study (HOPS) compared with the US general population, 200-2006. Clin Infect Dis 2011; 52: 1061-1068.

7. Sharma A, Shi Q, Hoover DR, et al. increased fracture incidence in middle-aged HIV-infected and uninfected women: updated results from the Women's Interagency HIV Study. JAIDS 2015; 70: 5461.

8. Grund B, Peng G, Gibert CL, et al. Continous antiretroviral therapy decreases bone mineral density. AIDS 2009; 23: 1519-1529.

9. Hansen AB, Obel N, Nielsen H, Pedersen C, Gerstoft J. Bone mineral density changes in protease inhibitor-sparing vs. nucleoside reverse transcriptase inhibitor-sparing highly active antiretroviral therapy: data from randomized trial. HIV Med 2011; 12: 157-165

10. McComsey GA, Kitch D, Daar ES, et al. Bone mineral density and fracture in antiretroviral-naïve persons randomized to receive abacavir-lamivudine or tenofovir disoproxil fumarate-emtricitabine along with efavirenz or atazanavir-ritonavir: Aids Clinical Trials Group A5224s, a substudy of ACTG A5202. J Infect Dis 2011; 203: 1791-1801.

11. Stellbrink HJ, Orkin C, Arribas JR, et al. Comparison of changes in bone density and turnover with abacavir-lamivudine versus tenofovir-emtricitabine in HIV-infected adults: 48-week results from the ASSERT study. Clin Infect Dis 2010; 51: 963-972.

12. Duvivier C, Kolta S, Assoumou L, et al. Greater decrease in bone mineral density with protease inhibitor regimens compared with non nucleoside reverse transcriptase inhibitor regimens in HIV-1 infected naïve patients. AIDS 2009; 23: 817-824

13. Bonnet E, Ruidavets JB, Genoux A, et al. Early loss of bone mineral density is correlated with a gain of fat mass in patients starting a protease inhibitor containing regimen: the prospective Lipotrip study. BMC infection diseases 2013, 13: 293

14. Yu EW, Thomas BJ, Brown JK, Finkelstein JS. Simulated increases in body fat and errors in bone mineral density measurements by DXA and QCT. J Bone Miner Res 2012, 27: 119-24

15. Liu AY, Vittinghoff E, Sellmeyer DE, et al. Bone mineral density in HIV-negative men participating 
in a tenofovir preexposure prophylaxis randomized clinical trial in San Francisco. PLoS One 2011; 6: e23688

16. Mulligan K, Glidden DV, Anderson PE, Liu A, et al. Effects of Emtricitabine/Tenofovir on Bone Mineral Density in HIV-Negative Persons in aRandomized, Double-Blind, Placebo-Controlled trial. CID 2015; 61: 572-580

17. Hoy j, Grund B, Roediger M, et al. Interruption or deferral of antiretroviral therapy reduces markers of bone turnover compared with continuous therapy: the SMART Body Composition substudy. J Bone Miner Res 2013; 28:1264-74

18. Hansen AB, Gerstoft J, Kronborg G, et al. Incidence of low and high-energy fractures in persons with and without HIV infection: a Danish population-based cohort study. AIDS 2012; 26: 285-293

19. Bedimo R, Maalouf NM, Zhang S, Drechsler H, Tebas P. osteoporotic fracture risk associated with cumulative exposure to tenofovir and other antiretroviral agents. AIDS 2012; 26: 825-831

20. Mundy LM, Youk AO, McComsey GA, Bowlin SJ. Overall benefit of antiretroviral treatment on the risk of fracture in HIV: nested case-control analysis in a health-insured population. AIDS 2012; 26: 1073-1082

21. Gedmintas L, Wright EA, Dong Y, et al. Factors associated with fractures in HIV-infected persons: which factors matter? Osteoporos Int 2017; 28: 239-244

22. Yin MT, Kendall MA, Wu Xingye, et al. Fracture after antiretroviral initiation. AIDS 2012; 26: 2175-2184

23. Borges AH, Hoy J, Florence E, et al. Antiretrovirals, fractures and osteonecrosis in a large international HIV cohort. CID 2017; 64: 1413-1421.

24. Gonciulea A, Wang R, Althoff KN, et al. An increased rate of fracture occurs a decade earlier in HIV+ compared with HIV- men. AIDS 2017; 31: 1435-1443.

25. Garcia MG, Larrinaga-Torrontegui U, Eduardo Martinez M, Lertxundi U, Palacio-Zabalza I, Aguirre C. Fractures Related to Tenofovir: A Case/Noncase Study in the European Pharmacovigilance Database. Am J Ther. 2018

26. Kanis JA, Johnell O, Oden A, Johansson H, Mccloskey E. FRAXTM and the assessment of fracture probability in men and women from the UK. Osteoporos Int. 2008; 19: 385-397.

27. Mary-Krause M, Grabar S, Lièvre L, et al. Cohort Profile: French hospital database on HIV (FHDHANRS CO4). Int. J. Epidemiol. 2014; 43: 1425-1436

28. Lang S, Mary-Krause M, Simon A, et al. HIV Replication and Immune Status Are Independent Predictors of the Risk of Myocardial Infarction in HIV-Infected Individuals. CID 2012; 55: 600-607

29. Suissa S. Novel approaches to pharmacoepidemiology study design and statistical analysis. In: Strom B., ed. Pharmacoepidemiology. 4th ed. Wiley; 2005; 811-29.

30. Richardson DB. An incidence density sampling program for nested case-control analyses. Occup Environ Med 2004; 61: e59

31. Tinago W, Cotter AG, Sabin CA, et al. Predictors of longitudinal change in bone mineral density in a cohort of HIV-positive and negative patients AIDS 2017; 31: 643-652

32. Grant PM, Kitch D, McComsey GA, et al. Long-term Bone Mineral Density Changes in Antiretroviral-Treated HIV-Infected Individuals. JID 2016; 214: 607-611 
33. Stone KL, Seeley DG, Lui LY, et al for the study of Osteoporotic Fractures Research Group. BMD at multiple sites and risk of fractures of multiples types: long term results from the Study of Osteoporotic Fractures. J Bone Miner Res 2003; 18: 1947-1954. 
Fig. 1. Flow chart

- 87 medical records in centers not participating to the study

- 78 medical records not found in participating centers

- 149 public road accidents

- 372 fractures at non osteoporotic sites

- 57 others reasons

- 22 without fractures

FHDH ANRS CO4

HIV-infected individuals enrolled in FHDH while ARV naïve and followed between 2000 and 2010 $\mathrm{N}=62776$

HIV-infected individuals with a first prospectively reported fracture $\mathbf{N}=1026$

\begin{tabular}{|c|}
\hline HIV-infected individuals with reviewed fractures \\
$\mathbf{N}=861$ \\
\hline $\begin{array}{c}\text { HIV-infected individuals with fractures of low energy } \\
\text { at a possible osteoporotic site } \\
N=261\end{array}$ \\
\hline HIV-infected individuals matched to at leastone \\
control \\
$N=254$
\end{tabular}

254 cases matched to 376 controls 
Table 1. Characteristics of participants

\begin{tabular}{|c|c|c|c|c|c|}
\hline & \multicolumn{2}{|c|}{ Cases $(n=254)$} & \multicolumn{2}{|c|}{ Controls (n=376) } & \multirow[t]{2}{*}{$\begin{array}{c}\text { Controls } \\
(n=376)\end{array}$} \\
\hline & $\mathrm{n}$, median & $\mathrm{n}$, median & $\mathrm{n}$, median & $\%,[\mathrm{IQR}]$ & \\
\hline Age & 49 & [42-58] & 49 & [42-57] & \\
\hline \multicolumn{6}{|l|}{ Gender } \\
\hline Men & 170 & 66.9 & 246 & 65.4 & \\
\hline Women & 84 & 33.1 & 130 & 34.6 & \\
\hline \multicolumn{6}{|l|}{ HIV related factors: } \\
\hline \multicolumn{6}{|l|}{ HIV-1 diagnosis period } \\
\hline$<1997$ & 181 & 71.3 & 250 & 66.5 & \\
\hline$\geq 1997$ & 73 & 28.7 & 126 & 33.5 & \\
\hline \multicolumn{6}{|l|}{ Period of enrolment in FHDH } \\
\hline$\leq 1996$ & 172 & 67.7 & 135 & 35.9 & $<0.0001$ \\
\hline $1997-2001$ & 37 & 14.6 & 100 & 26.6 & \\
\hline 2002-2010 & 45 & 17.7 & 141 & 37.5 & \\
\hline \multicolumn{6}{|l|}{ Transmission group } \\
\hline MSM & 86 & 33.9 & 74 & 19.7 & $<0.0001$ \\
\hline Injecting drug use & 56 & 22.0 & 39 & 10.4 & \\
\hline Other & 112 & 44.1 & 263 & 69.9 & \\
\hline \multicolumn{6}{|l|}{ Period of ARV initiation } \\
\hline Naïve & 8 & & 36 & & \\
\hline$<1997$ & 104 & 42.3 & 134 & 39.4 & 0.636 \\
\hline 1997-2001 & 73 & 29.7 & 103 & 30.3 & \\
\hline 2002-2010 & 69 & 28.0 & 103 & 30.3 & \\
\hline Number of ARVs & 6.0 & {$[4.0-10.0]$} & 5.0 & {$[3.0-8.0]$} & 0.0003 \\
\hline Cumulative duration of ARV exposure (months) & 78.2 & [34.9-119] & 68.1 & {$[21.7-123]$} & 0.438 \\
\hline Nadir CD4 (cells $\left./ \mathbf{m m}^{3}\right) \dagger$ & 172 & {$[75-298]$} & 196 & {$[82-287]$} & $0.685^{* *}$ \\
\hline CD4 (cells/mm $\left.\mathbf{m m}^{3}\right)$ at index date $\dagger$ & 436 & {$[293-592]$} & 451 & {$[310-612]$} & $0.220 * *$ \\
\hline $\operatorname{CD8}\left(/ \mathrm{mm}^{3}\right)$ at index date $\dagger$ & 836 & {$[589-1208]$} & 872 & {$[648-1151]$} & $0.478^{* *}$ \\
\hline CD4/CD8 at index date $\dagger$ & 0.49 & {$[0.32-0.76]$} & 0.51 & {$[0.35-0.74]$} & $0.824^{* *}$ \\
\hline Viral load (copies/ml) at index date $\dagger:<50$ copies/ml & 166 & 65.3 & 253 & 67.3 & $0.760^{* *}$ \\
\hline \multicolumn{6}{|l|}{ Prior AIDS event } \\
\hline No & 175 & 68.9 & 302 & 80.3 & 0.001 \\
\hline Yes & 79 & 31.1 & 74 & 19.7 & \\
\hline \multicolumn{6}{|l|}{ HCV antibody status } \\
\hline Negative & 235 & 92.5 & 356 & 94.7 & 0.314 \\
\hline Positive & 19 & 7.5 & 20 & 5.3 & \\
\hline \multicolumn{6}{|l|}{ Classical risk factors for fracture: } \\
\hline \multicolumn{6}{|l|}{ Sub-Saharan origin } \\
\hline Yes & 10 & 3.9 & 43 & 11.4 & 0.002 \\
\hline No & 244 & 96.1 & 333 & 88.6 & \\
\hline \multicolumn{6}{|l|}{ BMI } \\
\hline Missing & 44 & 17.3 & 49 & 13.0 & \\
\hline Thin $(<18.5)$ & 33 & 13.0 & 23 & 6.1 & $0.045^{* *}$ \\
\hline Normal $(18.5 \leq \mathrm{BMI} \leq 25)$ & 137 & 53.9 & 214 & 56.9 & \\
\hline Overweight $(>25)$ & 84 & 33.1 & 139 & 37.0 & \\
\hline \multicolumn{6}{|l|}{ Smoking status } \\
\hline Missing & 23 & 9.1 & 21 & 5.6 & \\
\hline No & 105 & 41.3 & 181 & 48.1 & $0.132 * *$ \\
\hline Past & 54 & 21.3 & 61 & 16.3 & \\
\hline Current & 95 & 37.4 & 134 & 35.6 & \\
\hline \multicolumn{6}{|l|}{ Alcohol consumption } \\
\hline Missing & 43 & 16.9 & 44 & 11.7 & \\
\hline$\leq 2$ glasses/day & 193 & 76.0 & 326 & 86.7 & $0.002 * *$ \\
\hline$>2$ glasses/day & 61 & 24.0 & 50 & 13.3 & \\
\hline
\end{tabular}

History of hip fracture without major trauma in the father / mother 


\begin{tabular}{|c|c|c|c|c|c|}
\hline & \multicolumn{2}{|c|}{ Cases $(n=254)$} & \multicolumn{2}{|c|}{ Controls (n=376) } & \multirow[t]{2}{*}{$\begin{array}{c}\text { Controls } \\
(n=376)\end{array}$} \\
\hline & $\mathrm{n}$, median & $\mathrm{n}$, median & $\mathrm{n}$, median & $\%,[\mathrm{IQR}]$ & \\
\hline Missing & 120 & 47.2 & 121 & 32.2 & \\
\hline No & 246 & 96.9 & 366 & 97.3 & $0.993 * *$ \\
\hline Yes & 8 & 3.1 & 10 & 2.7 & \\
\hline \multicolumn{6}{|c|}{ Prior systemic glucocorticoid exposure } \\
\hline Missing & 49 & 19.3 & 49 & 13.0 & \\
\hline No & 229 & 90.2 & 362 & 96.3 & $0.011 * *$ \\
\hline Yes & 25 & 9.8 & 14 & 3.7 & \\
\hline \multicolumn{6}{|c|}{$\begin{array}{l}\text { Chronic kidney disease: dialysis or eGFR (CKD- } \\
\text { EPI<60) }\end{array}$} \\
\hline Missing & 31 & 12.2 & 48 & 12.8 & \\
\hline No & 222 & 87.4 & 336 & 89.4 & $0.282 * *$ \\
\hline Yes & 32 & 12.6 & 40 & 10.6 & \\
\hline \multicolumn{6}{|c|}{ Menopause before the fracture or age $>50$ years } \\
\hline Missing & 0 & 0.0 & 1 & 0.3 & \\
\hline No & 38 & 45.8 & 64 & 49.6 & $0.431 * * *$ \\
\hline Yes & 45 & 54.2 & 65 & 50.4 & \\
\hline Not relevant & 171 & & 247 & & \\
\hline \multicolumn{6}{|c|}{ Known osteoporosis before the fracture } \\
\hline Missing & 124 & 48.8 & 121 & 32.2 & \\
\hline No & 228 & 89.8 & 368 & 97.9 & $0.002 * *$ \\
\hline Yes & 26 & 10.2 & 8 & 2.1 & \\
\hline
\end{tabular}

* P values by conditional logistic regression

** $\mathrm{P}$ values after imputing missing values

*** Test restricted to women, after imputing missing values

$\dagger$ Number missing values for CD4 nadir: $n=7$, CD4: $n=6$, CD8: $n=35$, CD4/CD8: $n=35$, VL: $n=10$. 


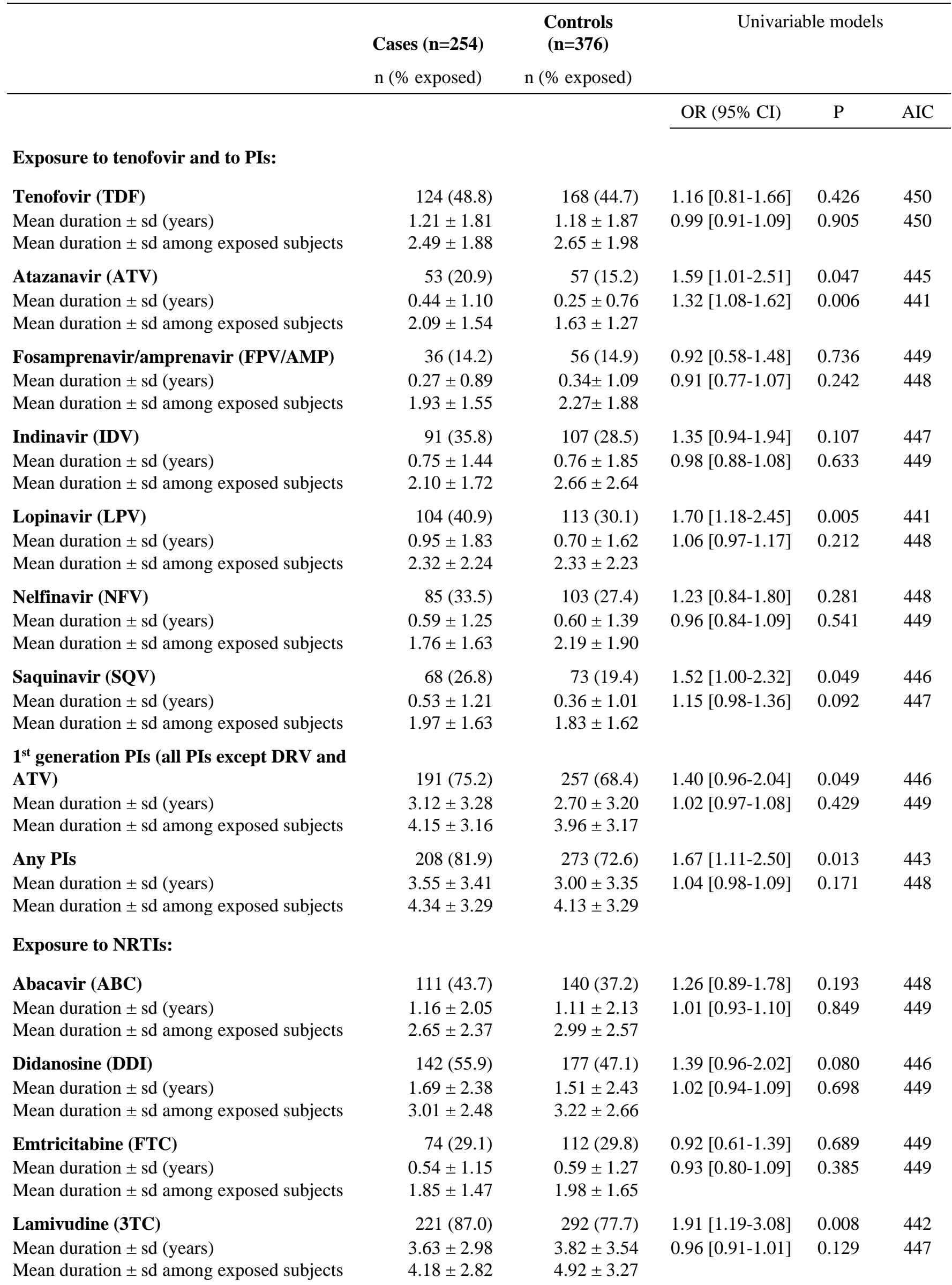


Univariable models

Cases $(\mathbf{n}=254)$

$(n=376)$

$n$ (\% exposed) $n$ (\% exposed)

\section{Stavudine (D4T)}

Mean duration \pm sd (years)

Mean duration \pm sd among exposed subjects

\section{Zalcitabine (DDC)}

Mean duration \pm sd (years)

Mean duration \pm sd among exposed subjects

\section{Zidovudine (ZDV)}

Mean duration \pm sd (years)

Mean duration \pm sd among exposed subjects

\section{Exposure to NNRTIs:}

\section{Efavirenz (EFV)}

Mean duration \pm sd (years)

Mean duration \pm sd among exposed subjects

\section{Nevirapine (NVP)}

Mean duration \pm sd (years)

Mean duration \pm sd among exposed subjects

\begin{tabular}{rrrrr} 
& & OR (95\% CI) & P & AIC \\
\cline { 3 - 5 } $137(53.9)$ & $161(42.8)$ & $1.60[1.10-2.32]$ & 0.014 & 443 \\
$1.58 \pm 2.09$ & $1.44 \pm 2.23$ & $1.02[0.94-1.10]$ & 0.666 & 449 \\
$2.92 \pm 2.05$ & $3.36 \pm 2.27$ & & & \\
$62(24.4)$ & $65(17.3)$ & $1.52[1.00-2.32]$ & 0.053 & 446 \\
$0.25 \pm 0.59$ & $0.31 \pm 0.92$ & $0.85[0.68-1.07]$ & 0.166 & 447 \\
$1.01 \pm 0.82$ & $1.77 \pm 1.51$ & & & \\
$203(79.9)$ & $269(71.5)$ & $1.58[1.04-2.41]$ & 0.034 & 445 \\
$3.14 \pm 3.16$ & $2.89 \pm 3.40$ & $1.01[0.96-1.06]$ & 0.634 & 449 \\
$3.93 \pm 3.06$ & $4.04 \pm 3.39$ & & & \\
& & & & \\
$95(37.4)$ & $127(33.8)$ & $1.17[0.83-1.65]$ & 0.386 & 449 \\
$0.82 \pm 1.78$ & $1.03 \pm 2.22$ & $0.94[0.86-1.02]$ & 0.121 & 447 \\
$2.19 \pm 2.35$ & $3.04 \pm 2.92$ & & & \\
$85(33.5)$ & $78(20.7)$ & $1.93[1.32-2.83]$ & 0.0007 & 438 \\
$0.72 \pm 1.68$ & $0.57 \pm 1.60$ & $1.04[0.94-1.15]$ & 0.480 & 449 \\
$2.14 \pm 2.34$ & $2.73 \pm 2.55$ & & & \\
\hline
\end{tabular}


Table 3. Multivariable models of ARV exposure

\begin{tabular}{|c|c|c|c|c|c|c|}
\hline & \multicolumn{2}{|c|}{$\begin{array}{c}\text { OR model } 1 \\
\text { Cumulative exposure }\end{array}$} & \multicolumn{2}{|c|}{$\begin{array}{c}\text { OR model } 2 \\
\text { Exposure (yes/no) }\end{array}$} & \multicolumn{2}{|c|}{$\begin{array}{c}\text { OR model } 3 \\
\text { Exposure (yes/no) except for ATV, } \\
\text { DRV, FPV, FTC, EFV }\end{array}$} \\
\hline & $\begin{array}{l}\text { adjusted for } \\
\text { ARV }\end{array}$ & $\begin{array}{c}\text { adjusted for } \\
\text { ARV+confounders* }\end{array}$ & $\begin{array}{l}\text { adjusted for } \\
\text { ARV }\end{array}$ & $\begin{array}{c}\text { adjusted for } \\
\text { ARV+confounders* }\end{array}$ & $\begin{array}{c}\text { adjusted for } \\
\text { ARV }\end{array}$ & $\begin{array}{c}\text { adjusted for } \\
\text { ARV+confounders* }\end{array}$ \\
\hline & $\mathrm{AIC}=451$ & AIC $=329$ & $\mathrm{AIC}=458$ & $\mathrm{AIC}=345$ & $\mathrm{AIC}=448$ & $\mathrm{AIC}=332$ \\
\hline & & & & & & \\
\hline Tenofovir (TDF) & $1.07[0.93-1.22]$ & 1.04 [0.86-1.27] & 1.05 [0.63-1.75] & $1.21[0.61-2.39]$ & 1.09 [0.70-1.69] & $1.37[0.74-2.53]$ \\
\hline Atazanavir (ATV) & 1.46 [1.15-1.85] & $1.52[1.06-2.17]$ & 1.67 [1.01-2.73] & $1.89[0.96-3.72]$ & $1.41[1.12-1.77]$ & 1.49 [1.04-2.13] \\
\hline $\begin{array}{l}\text { Fosamprenavir/amp } \\
\text { renavir (FPV/AMP) }\end{array}$ & 0.98 [0.81-1.19] & $1.02[0.75-1.38]$ & $0.82[0.48-1.41]$ & 0.72 [0.34-1.53] & 0.90 [0.74-1.09] & $0.98[0.72-1.33]$ \\
\hline Indinavir (IDV) & $1.02[0.89-1.16]$ & $1.09[0.88-1.34]$ & $1.00[0.64-1.56]$ & $1.18[0.66-2.14]$ & $1.04[0.67-1.63]$ & $1.29[0.70-2.38]$ \\
\hline Lopinavir (LPV) & $1.10[0.98-1.23]$ & $1.04[0.87-1.25]$ & $1.47[0.98-2.22]$ & $1.29[0.73-2.27]$ & $1.46[0.95-2.22]$ & $1.13[0.63-2.04]$ \\
\hline Nelfinavir (NFV) & $0.93[0.80-1.07]$ & $0.95[0.77-1.16]$ & $0.89[0.57-1.40]$ & $0.89[0.49-1.62]$ & $0.84[0.53-1.35]$ & $0.87[0.47-1.64]$ \\
\hline Saquinavir (SQV) & $1.19[0.99-1.44]$ & $1.00[0.78-1.27]$ & $1.11[0.67-1.84]$ & $0.80[0.42-1.52]$ & 1.07 [0.64-1.78] & $0.73[0.38-1.41]$ \\
\hline 1st generation PIs** & 1.06 [0.99-1.13] & $1.01[0.91-1.12]$ & $1.02[0.65-1.61]$ & $0.96[0.51-1.80]$ & 1.00 [0.63-1.59] & $0.95[0.50-1.82]$ \\
\hline Any PI & 1.06 [1.00-1.14] & $1.02[0.92-1.12]$ & $1.39[0.87-2.21]$ & $1.25[0.66-2.35]$ & $1.27[0.80-2.04]$ & $1.10[0.58-2.10]$ \\
\hline $\begin{array}{l}\text { Exposure to } \\
\text { NRTIs: }\end{array}$ & & & & & & \\
\hline Abacavir (ABC) & 0.99 [0.90-1.09] & $0.98[0.86-1.12]$ & 1.04 [0.68-1.57] & $1.41[0.80-2.48]$ & $1.08[0.71-1.64]$ & $1.45[0.82-2.56]$ \\
\hline Didanosine (DDI) & $0.98[0.89-1.07]$ & $0.95[0.83-1.08]$ & $0.97[0.61-1.53]$ & $0.80[0.44-1.45]$ & 0.98 [0.61-1.55] & $0.79[0.43-1.47]$ \\
\hline Emtricitabine (FTC) & $0.80[0.64-1.01]$ & $0.84[0.60-1.18]$ & $0.80[0.45-1.44]$ & $0.97[0.45-2.08]$ & $0.86[0.70-1.06]$ & $0.87[0.65-1.17]$ \\
\hline Lamivudine (3TC) & $0.86[0.78-0.95]$ & $0.85[0.74-0.98]$ & $1.22[0.62-2.43]$ & 1.31 [0.55-3.13] & $1.33[0.67-2.67]$ & 1.36 [0.56-3.32] \\
\hline Stavudine (D4T) & $1.15[1.01-1.30]$ & $1.04[0.87-1.24]$ & $1.16[0.70-1.91]$ & $0.71[0.36-1.41]$ & $1.22[0.73-2.02]$ & $0.77[0.38-1.55]$ \\
\hline Zalcitabine (DDC) & $0.69[0.53-0.91]$ & $0.66[0.45-0.97]$ & $1.27[0.77-2.08]$ & $0.79[0.40-1.56]$ & $1.32[0.80-2.19]$ & $0.86[0.42-1.74]$ \\
\hline Zidovudine (ZDV) & 1.13 [1.04-1.22] & $1.11[0.99-1.24]$ & 1.08 [0.59-1.96] & $1.07[0.50-2.30]$ & $1.01[0.55-1.86]$ & $0.99[0.45-2.21]$ \\
\hline $\begin{array}{l}\text { Exposure to } \\
\text { NNRTIs: }\end{array}$ & & & & & & \\
\hline Efavirenz (EFV) & 0.98 [0.88-1.09] & $0.81[0.69-0.96]$ & $1.09[0.74-1.61]$ & $0.90[0.54-1.51]$ & 0.95 [0.86-1.05] & $0.82[0.70-0.96]$ \\
\hline Nevirapine (NVP) & 1.05 [0.93-1.18] & 0.98 [0.83-1.16] & 1.79 [1.17-2.73] & $1.81[1.05-3.13]$ & 1.70 [1.09-2.63] & $1.60[0.89-2.87]$ \\
\hline
\end{tabular}

*Potential confounders: HIV transmission group (MSM/injecting drug use/others), geographic origin (Sub-Saharan Africa/others), AIDS status (yes/no), BMI ([18.5-25.0]/<18.5/>25.0), smoking status (no/past/current), alcohol consumption ( $\leq 2$ glasses/day/>2glasses/day), exposure to systemic glucocorticoids (no/yes), period of enrolment ( $\leq 1996 / 1997-2001 / \geq 2002)$.

**All PIs except darunavir and atazanavir 
Supplementary Table 1. Summary of studies on the association between eposure to ARV and the risk of fracture.

\begin{tabular}{|c|c|c|c|c|c|c|c|c|c|c|c|}
\hline \multirow[t]{2}{*}{ Study } & \multirow{2}{*}{$\begin{array}{l}\text { Study } \\
\text { design }\end{array}$} & \multirow[t]{2}{*}{ Fracture, $\mathrm{n}$} & \multirow{2}{*}{$\begin{array}{l}\text { Exposure } \\
\text { measurement }\end{array}$} & \multirow{2}{*}{$\begin{array}{l}\text { Definition } \\
\text { fracture }\end{array}$} & \multicolumn{3}{|c|}{ Adjustement factors } & \multirow{2}{*}{$\begin{array}{l}\text { Statistic } \\
\text { model }\end{array}$} & \multicolumn{3}{|l|}{ Results on ARVs } \\
\hline & & & & & $\begin{array}{l}\text { HIV } \\
\text { parameters }\end{array}$ & $\begin{array}{l}\text { Fractures risk } \\
\text { factors }\end{array}$ & Others factors & & TDF effect & PI effect & $\begin{array}{l}\text { Others ARVs } \\
\text { effect }\end{array}$ \\
\hline $\begin{array}{l}\text { Womack et } \\
\text { al. [5] } \\
\text { Plos One } \\
2011\end{array}$ & $\begin{array}{l}\text { Cohort HIV+ } \\
\text { Men }\end{array}$ & $\begin{array}{l}\text { Number of } \\
\text { fractures } \\
\text { in HIV } \\
\text { patients } \\
\text { was not } \\
\text { reported } \\
\text { By } \\
\text { calulation } \\
\text { can be } \\
\text { estimated } \\
\text { as } 602\end{array}$ & $\begin{array}{l}\text { Current use } \\
\text { Cumulative } \\
\text { exposure }\end{array}$ & $\begin{array}{l}\text { Hip,vertebral } \\
\text { and humeral } \\
\text { fractures of } \\
\text { low and high } \\
\text { energy }\end{array}$ & $\begin{array}{l}\text { Current CD4 } \\
\text { count }\end{array}$ & $\begin{array}{l}\text { Age,ethnicity,BMI, } \\
\text { current cigarette } \\
\text { smoking, } \\
\text { corticosteroid use, } \\
\text { alcohol abuse }\end{array}$ & $\begin{array}{l}\text { proton pump } \\
\text { inhibitor, } \\
\text { congestive } \\
\text { heart failure, } \\
\text { pulmonary } \\
\text { disease, } \\
\text { peripheral } \\
\text { vascular } \\
\text { disease, } \\
\text { diabetes } \\
\text { melitus, major } \\
\text { depressive } \\
\text { disorder, } \\
\text { coronary } \\
\text { artery disease, } \\
\text { liver disease, } \\
\text { renal } \\
\text { insufficiency }\end{array}$ & $\begin{array}{l}\text { Cox } \\
\text { regression }\end{array}$ & $\begin{array}{l}\text { Current use: } \\
1.29[0.99-1.70] \\
\text { Author } \\
\text { conclusion: } \\
\text { No association }\end{array}$ & $\begin{array}{l}1.41[1.16-1.70] \\
\text { Author } \\
\text { conclusion: } \\
\begin{array}{l}\text { Association not } \\
\text { necessarily } \\
\text { causal }\end{array}\end{array}$ & Not analysed \\
\hline $\begin{array}{l}\text { Sharma et } \\
\text { al. [7] } \\
\text { JAIDS } 2015\end{array}$ & $\begin{array}{l}\text { Cohort HIV+ } \\
\text { women }\end{array}$ & 300 & $\begin{array}{l}\text { Use at index visit } \\
\text { Cumulative } \\
\text { exposure }\end{array}$ & $\begin{array}{l}\text { Any fractures } \\
\text { (fragility or } \\
\text { non-fragility) } \\
\text { at any body } \\
\text { site }\end{array}$ & & & & $\begin{array}{l}\text { Bivariate } \\
\text { analysis }\end{array}$ & $\begin{array}{l}\text { Use (index): } \\
1.24 \text { [0.98-1.56] } \\
\text { Cumulative } \\
\text { exposure: } \\
1.0 \text { [0.95-1.05] } \\
\text { Author } \\
\text { conclusion: } \\
\text { No association }\end{array}$ & $\begin{array}{l}\text { Use (index): } \\
1.10 \text { [0.98-1.39] } \\
\text { Cumulative } \\
\text { exposure: } \\
1.02 \text { [0.99-1.05] } \\
\text { Author } \\
\text { conclusion: } \\
\text { No association }\end{array}$ & $\begin{array}{l}\text { NRTI use: } \\
1.01 \text { [0.77-1.33] } \\
\text { NNRTI use: } \\
0.10 \text { [0.78-1.27] } \\
\text { Cumulative } \\
\text { exposure NRTI: } \\
1.02 \text { [0.99-1.05] } \\
\text { Cumulative } \\
\text { exposure } \\
\text { NNRTI: } \\
1.01 \text { [0.98-1.05] } \\
\text { Author } \\
\text { conclusion: } \\
\text { No association }\end{array}$ \\
\hline $\begin{array}{l}\text { Hansen et } \\
\text { al. [18] } \\
\text { AIDS 2012 }\end{array}$ & $\begin{array}{l}\text { Cohort } \\
\text { HIV+ not } \\
\text { infected by } \\
\text { HCV who } \\
\text { started cArt }\end{array}$ & 375 & Any use & $\begin{array}{l}\text { Wrist, } \\
\text { humerus, } \\
\text { hip,vertebral } \\
\text { or other } \\
\text { fractures of } \\
\text { low-energy }\end{array}$ & $\begin{array}{l}\text { CD4 before } \\
\text { start of } \\
\text { cART, AIDS } \\
\text { status, HIV } \\
\text { diagnostic } \\
\text { before or } \\
\text { after } 1 \text { jan. } \\
1995\end{array}$ & Age, sex, ethnicity & $\begin{array}{l}\text { Charlson } \\
\text { comorbidity } \\
\text { index (CCl) }\end{array}$ & $\begin{array}{l}\text { Cox } \\
\text { regression }\end{array}$ & $\begin{array}{l}1.2[0.8-1.7] \\
\text { Author } \\
\text { conclusion: } \\
\text { No association }\end{array}$ & Not analysed & $\begin{array}{l}\text { Efavirenz: } \\
1.1 \text { [0.8-1.4] } \\
\text { Abacavir: } \\
0.9 \text { [0.7-1.2] } \\
\text { Author } \\
\text { conclusion: } \\
\text { No association }\end{array}$ \\
\hline $\begin{array}{l}\text { Bedimo et } \\
\text { al. [19] }\end{array}$ & Cohort HIV+ & 951 & $\begin{array}{l}\text { Cumulative } \\
\text { exposure }\end{array}$ & Wrist, hip, & $\begin{array}{l}\text { No HIV } \\
\text { parameters }\end{array}$ & $\begin{array}{l}\text { Age,ethnicity, BMI, } \\
\text { tobacco use }\end{array}$ & $\begin{array}{l}\text { Diabetes, } \\
\text { chronic kidney }\end{array}$ & $\begin{array}{l}\text { Cox } \\
\text { regression }\end{array}$ & $\begin{array}{l}1.06[0.99-1.14] \\
\text { (per year) }\end{array}$ & $\begin{array}{l}1.03[0.97-1.09] \\
\text { (per year) }\end{array}$ & $\begin{array}{l}\text { Abacavir: NS } \\
\text { ZDV/D4T: NS }\end{array}$ \\
\hline
\end{tabular}




\begin{tabular}{|c|c|c|c|c|c|c|c|c|c|c|c|}
\hline \multirow[t]{2}{*}{ Study } & \multirow{2}{*}{$\begin{array}{l}\text { Study } \\
\text { design }\end{array}$} & \multirow[t]{2}{*}{ Fracture, $\mathrm{n}$} & \multirow{2}{*}{$\begin{array}{l}\text { Exposure } \\
\text { measurement }\end{array}$} & \multirow{2}{*}{$\begin{array}{l}\text { Definition } \\
\text { fracture }\end{array}$} & \multicolumn{3}{|c|}{ Adjustement factors } & \multirow{2}{*}{$\begin{array}{l}\text { Statistic } \\
\text { model }\end{array}$} & \multicolumn{3}{|l|}{ Results on ARVs } \\
\hline & & & & & $\begin{array}{l}\text { HIV } \\
\text { parameters }\end{array}$ & $\begin{array}{l}\text { Fractures risk } \\
\text { factors }\end{array}$ & Others factors & & TDF effect & PI effect & $\begin{array}{l}\text { Others ARVs } \\
\text { effect }\end{array}$ \\
\hline AIDS 2012 & $\begin{array}{l}\text { (98\% of } \\
\text { male } \\
\text { patients) }\end{array}$ & & & $\begin{array}{l}\text { vertebral } \\
\text { fractures. } \\
\text { Low-energy or } \\
\text { high energy } \\
\text { not reported }\end{array}$ & & & $\begin{array}{l}\text { disease, } \\
\text { hepatitis C } \\
\text { infection }\end{array}$ & & $\begin{array}{l}\text { Author } \\
\text { conclusion: } \\
\text { Association with } \\
\text { a modestly } \\
\text { increased } \\
\text { osteoporotic } \\
\text { fracture risk, no } \\
\text { longer significant } \\
\text { after controlling } \\
\text { for traditional } \\
\text { osteoporotic risk } \\
\text { factors } \\
\text { When restricting } \\
\text { the analysis to } \\
\text { individuals } \\
\text { entering the } \\
\text { cohort in the } \\
\text { cART era (1996- } \\
2009 \text { ) } \\
1.12 \text { [1.03-1.21] } \\
\text { Cumulative } \\
\text { exposure to TDF } \\
\text { was } \\
\text { independently } \\
\text { predictive of } \\
\text { increased risk of } \\
\text { osteoporotic } \\
\text { fracture in the } \\
\text { HAART era. }\end{array}$ & $\begin{array}{l}\text { Author } \\
\text { conclusion: } \\
\text { Association with } \\
\text { a modestly } \\
\text { increased } \\
\text { osteoporotic } \\
\text { fracture risk, no } \\
\text { longer significant } \\
\text { after controlling } \\
\text { for traditional } \\
\text { osteoporotic risk } \\
\text { factors } \\
\text { When restricting } \\
\text { the analysis to } \\
\text { individuals } \\
\text { entering the } \\
\text { cohort in the } \\
\text { cART era (1996- } \\
2009) \\
1.05 \text { [0.97-1.13] } \\
\text { LPV/RTV had } \\
1.09 \text { [1.00-1.20] }\end{array}$ & $\begin{array}{l}\text { NNRTI: NS } \\
\text { Author } \\
\text { conclusion: } \\
\text { No association }\end{array}$ \\
\hline $\begin{array}{l}\text { Mundy et al. } \\
\text { [20] } \\
\text { AIDS } 2012\end{array}$ & $\begin{array}{l}\text { Nested } \\
\text { case-control } \\
\text { matched on } \\
\text { sex and age } \\
\text { in cohort } \\
\text { HIV+ }\end{array}$ & $\begin{array}{l}2477 \\
9144 \\
\text { controls }\end{array}$ & $\begin{array}{l}\text { Cumulative } \\
\text { exposure except } \\
\text { for ARV with } 30 \text { or } \\
\text { less exposed } \\
\text { cases as darunavir } \\
\text { was unexposed/ } \\
\text { exposed }\end{array}$ & $\begin{array}{l}\text { sites of } \\
\text { fractures not } \\
\text { reported } \\
\text { low-energy } \\
\text { fractures }\end{array}$ & $\begin{array}{l}\text { advanced } \\
\text { HIV AIDS } \\
\text { (category } \\
\text { B/C) }\end{array}$ & $\begin{array}{l}\text { Low body weight, } \\
\text { excess steroid } \\
\text { use, alcohol } \\
\text { abuse, treatment } \\
\text { for osteoporosis } \\
\text { with } \\
\text { bisphosphonates }\end{array}$ & $\begin{array}{l}\text { Prior fracture, } \\
\text { low physical } \\
\text { activity, } \\
\text { hepatitis C } \\
\text { infection, }\end{array}$ & $\begin{array}{l}\text { Conditional } \\
\text { logistic } \\
\text { regression }\end{array}$ & $\begin{array}{l}\text { Decreased risk: } \\
\text { Not exposed: } 1 \\
<3.5 \text { months: } \\
0.83 \text { [0.68-1.01] } \\
\text { [3.5- 8[ months: } \\
0.78 \text { [0.64-0.96] } \\
\text { [8- } 17 \text { [ months: } \\
0.68 \text { [0.56-0.82] } \\
\geq 17 \text { months: } \\
0.65 \text { [0.53-0.79] } \\
\text { Author } \\
\text { conclusion: }\end{array}$ & $\begin{array}{l}\text { Overall PI: NS } \\
\text { However for } \\
\text { Darunavir: } \\
1.95 \text { [1.05-3.56] } \\
\text { Saquinavir: } \\
<3 \text { months vs } \\
\text { not exposed: } \\
1.93 \text { [1.27-2.93] } \\
\text { Author } \\
\text { conclusion: } \\
\text { An increased } \\
\text { risk for fracture }\end{array}$ & $\begin{array}{l}\text { Decreased risk: } \\
\text { NRTI: } \\
\text { <4.5 months vs } \\
\text { not exposed: } \\
0.83 \text { [0.72-0.97] } \\
\text { NNRTI: } \\
\geq 18 \text { months: } \\
0.59 \text { [0.49-0.70] } \\
\text { Efavirenz: } \\
\geq 16 \text { months: } \\
0.55 \text { [0.45-0.67] } \\
\text { Emtricitabine: }\end{array}$ \\
\hline
\end{tabular}




\begin{tabular}{|c|c|c|c|c|c|c|c|c|c|c|c|}
\hline \multirow[t]{2}{*}{ Study } & \multirow{2}{*}{$\begin{array}{l}\text { Study } \\
\text { design }\end{array}$} & \multirow[t]{2}{*}{ Fracture, $\mathrm{n}$} & \multirow{2}{*}{$\begin{array}{l}\text { Exposure } \\
\text { measurement }\end{array}$} & \multirow{2}{*}{$\begin{array}{l}\text { Definition } \\
\text { fracture }\end{array}$} & \multicolumn{3}{|c|}{ Adjustement factors } & \multirow{2}{*}{$\begin{array}{l}\text { Statistic } \\
\text { model }\end{array}$} & \multicolumn{3}{|l|}{ Results on ARVs } \\
\hline & & & & & $\begin{array}{l}\text { HIV } \\
\text { parameters }\end{array}$ & $\begin{array}{l}\text { Fractures risk } \\
\text { factors }\end{array}$ & Others factors & & TDF effect & PI effect & $\begin{array}{l}\text { Others ARVs } \\
\text { effect }\end{array}$ \\
\hline & & & & & & & & & $\begin{array}{l}\text { Association with } \\
\text { an reduced risk } \\
\text { for fracture }\end{array}$ & $\begin{array}{l}\text { associated with } \\
\text { DRV and SQV. }\end{array}$ & $\begin{array}{l}12 \text { months: } \\
0.51 \text { [0.40-0.65] } \\
\text { Lamivudine: } \\
\geq 19.5 \text { months: } \\
0.64 \text { [0.55-0.75] } \\
\text { Zidovudine } \\
\geq 19 \text { months: } \\
0.63 \text { [0.52-0.77] } \\
\text { Abacavir: NS } \\
\text { Didanosine: NS } \\
\text { Stavudine: NS } \\
\text { Zalcitabine: NS } \\
\text { T20: NS } \\
\text { Author } \\
\text { conclusion: } \\
\text { A reduced risk } \\
\text { for fracture } \\
\text { associated with } \\
\text { efavirenz, } \\
\text { emtricitabine, } \\
\text { lamivudine, and } \\
\text { zidovudine }\end{array}$ \\
\hline $\begin{array}{l}\text { Gedmintas } \\
\text { et al. [21] } \\
\text { Osteopor Int } \\
2017\end{array}$ & Cohort HIV+ & 180 & $\begin{array}{l}\text { TDF users } \\
\text { (no/yes) }\end{array}$ & $\begin{array}{l}\text { Fractures at } \\
\text { any site of } \\
\text { low and high } \\
\text { energy }\end{array}$ & $\begin{array}{l}\text { Nadir CD4, } \\
\text { history of an } \\
\text { AlDS- } \\
\text { defining } \\
\text { illness }\end{array}$ & $\begin{array}{l}\text { Age, sex, ethnicity, } \\
\text { corticosteroid use, } \\
\text { alcohol abuse, } \\
\text { vitamin D } \\
\text { supplement use, } \\
\text { osteonecrosis, } \\
\text { osteoporosis }\end{array}$ & $\begin{array}{l}\text { Prior fracture, } \\
\text { history of falls, } \\
\text { obstructive } \\
\text { lung disease, } \\
\text { hepatitis C } \\
\text { infection, } \\
\text { study entry } \\
\text { year }\end{array}$ & $\begin{array}{l}\text { Pooled } \\
\text { logistic } \\
\text { regression }\end{array}$ & $\begin{array}{l}0.8 \text { [0.6-1.1] } \\
\text { Author } \\
\text { conclusion: } \\
\text { No association }\end{array}$ & Not analysed & Not analysed \\
\hline $\begin{array}{l}\text { Yin et al. } \\
\text { [22] } \\
\text { AIDS } 2012\end{array}$ & Cohort HIV+ & 80 & $\begin{array}{l}\text { Cumulative } \\
\text { exposure }\end{array}$ & $\begin{array}{l}\text { fractures at } \\
\text { wrist, hip, } \\
\text { spine, ankle, } \\
\text { foot, rib, } \\
\text { clavicle, hand } \\
\text { and pelvis } \\
\text { low or high } \\
\text { energy not } \\
\text { reported }\end{array}$ & & & & $\begin{array}{l}\text { Cox } \\
\text { regression }\end{array}$ & $\begin{array}{l}1.02[0.86-1.22] \\
\text { (per year) } \\
\text { Author } \\
\text { conclusion: } \\
\text { No association }\end{array}$ & $\begin{array}{l}1.04[0.93-1.17] \\
\text { (per year) } \\
\text { Author } \\
\text { conclusion: } \\
\text { No association }\end{array}$ & $\begin{array}{l}\text { NRTI: } \\
1.00 \text { [0.91-1.10] } \\
\text { NNRTI: } \\
1.00 \text { [0.89-1.12] } \\
\text { Abacavir: } \\
1.09 \text { [0.97-1.22] } \\
\text { Lamivudine: } \\
1.05 \text { [0.94-1.17] } \\
\text { Stavudine: } \\
0.93 \text { [0.81-1.07] } \\
\text { Zalcitabine: } \\
1.01 \text { [0.93-1.09] } \\
\text { efavirenz: }\end{array}$ \\
\hline
\end{tabular}




\begin{tabular}{|c|c|c|c|c|c|c|c|c|c|c|c|}
\hline \multirow[t]{2}{*}{ Study } & \multirow{2}{*}{$\begin{array}{l}\text { Study } \\
\text { design }\end{array}$} & \multirow[t]{2}{*}{ Fracture, $\mathrm{n}$} & \multirow{2}{*}{$\begin{array}{l}\text { Exposure } \\
\text { measurement }\end{array}$} & \multirow{2}{*}{$\begin{array}{l}\text { Definition } \\
\text { fracture }\end{array}$} & \multicolumn{3}{|c|}{ Adjustement factors } & \multirow{2}{*}{$\begin{array}{l}\text { Statistic } \\
\text { model }\end{array}$} & \multicolumn{3}{|l|}{ Results on ARVs } \\
\hline & & & & & $\begin{array}{l}\text { HIV } \\
\text { parameters }\end{array}$ & $\begin{array}{l}\text { Fractures risk } \\
\text { factors }\end{array}$ & Others factors & & TDF effect & PI effect & $\begin{array}{l}\text { Others ARVs } \\
\text { effect }\end{array}$ \\
\hline & & & & & & & & & & & $\begin{array}{l}1.02[0.91-1.14] \\
\text { Author } \\
\text { conclusion: } \\
\text { Not association }\end{array}$ \\
\hline $\begin{array}{l}\text { Borges AH } \\
\text { [23] } \\
\text { CID } 2017\end{array}$ & Cohort HIV+ & 132 & $\begin{array}{l}\text { Ever use } \\
\text { current use } \\
\text { cumulative } \\
\text { exposure }\end{array}$ & $\begin{array}{l}\text { fractures at } \\
\text { wrist,hip,spine } \\
\text { and arm } \\
\text { Low-energy or } \\
\text { high energy } \\
\text { not reported }\end{array}$ & $\begin{array}{l}\text { HIV } \\
\text { transmission } \\
\text { group, nadir } \\
\text { CD4, } \\
\text { CD4,viral } \\
\text { load, }\end{array}$ & $\begin{array}{l}\text { Age, } \\
\text { race,Europeen } \\
\text { region,BMI }\end{array}$ & $\begin{array}{l}\text { Prior fracture, } \\
\text { year of follow- } \\
\text { up,Hepatitis C, } \\
\text { AIDS defining } \\
\text { malignancy, } \\
\text { non malignant } \\
\text { AIDS event, } \\
\text { non AIDS } \\
\text { defining } \\
\text { malignancy,re } \\
\text { cent } \\
\text { cardiovascular } \\
\text { disease }\end{array}$ & $\begin{array}{l}\text { Poisson } \\
\text { regression } \\
\text { using } \\
\text { generalized } \\
\text { estimating } \\
\text { equations }\end{array}$ & $\begin{array}{l}\text { ever use: NS } \\
\text { current use: NS } \\
\text { cumulative } \\
\text { exposure: NS } \\
\text { Author } \\
\text { conclusion: } \\
\text { no association }\end{array}$ & & \\
\hline & & $\begin{array}{l}619 \text { in } 496 \\
\text { individuals }\end{array}$ & & All fractures & & & & & $\begin{array}{l}\text { ever use: } \\
1.40 \text { [1.15-1.70] } \\
\text { current use: } \\
1.25 \text { [1.05-1.49] } \\
\text { cumulative } \\
\text { exposure: } \\
1.08 \text { [0.94-1.25] } \\
\text { Author } \\
\text { conclusion: } \\
\text { Association with } \\
\text { an increased } \\
\text { risk of fractures }\end{array}$ & $\begin{array}{l}\text { Whether } \\
\text { modeled as } \\
\text { ever, current, or } \\
\text { cumulative, no } \\
\text { association } \\
\text { between } \\
\text { exposure to any } \\
\text { of the other } \\
\text { investigated } \\
\text { antiretrovirals } \\
\text { and fracture risk } \\
\text { was observed } \\
\text { (data not shown) } \\
\text { Author } \\
\text { conclusion: } \\
\text { No association }\end{array}$ & $\begin{array}{l}\text { Whether } \\
\text { modeled as } \\
\text { ever, current, or } \\
\text { cumulative, no } \\
\text { association } \\
\text { between } \\
\text { exposure to any } \\
\text { of the other } \\
\text { investigated } \\
\text { antiretrovirals } \\
\text { and fracture risk } \\
\text { was observed } \\
\text { (data not shown) } \\
\text { Author } \\
\text { conclusion: } \\
\text { No association }\end{array}$ \\
\hline
\end{tabular}




\begin{tabular}{|c|c|c|c|c|c|c|c|c|c|c|c|}
\hline \multirow[t]{2}{*}{ Study } & \multirow{2}{*}{$\begin{array}{l}\text { Study } \\
\text { design }\end{array}$} & \multirow[t]{2}{*}{ Fracture, $\mathrm{n}$} & \multirow{2}{*}{$\begin{array}{l}\text { Exposure } \\
\text { measurement }\end{array}$} & \multirow{2}{*}{$\begin{array}{l}\text { Definition } \\
\text { fracture }\end{array}$} & \multicolumn{3}{|c|}{ Adjustement factors } & \multirow{2}{*}{$\begin{array}{l}\text { Statistic } \\
\text { model }\end{array}$} & \multicolumn{3}{|l|}{ Results on ARVs } \\
\hline & & & & & $\begin{array}{l}\text { HIV } \\
\text { parameters }\end{array}$ & $\begin{array}{l}\text { Fractures risk } \\
\text { factors }\end{array}$ & Others factors & & TDF effect & PI effect & $\begin{array}{l}\text { Others ARVs } \\
\text { effect }\end{array}$ \\
\hline $\begin{array}{l}\text { Gonciulea et } \\
\text { al. [24] } \\
\text { AIDS } 2017\end{array}$ & $\begin{array}{l}\text { Cohort HIV+ } \\
\text { men }\end{array}$ & 70 & $\begin{array}{l}\text { Cumulative } \\
\text { exposure/5 years }\end{array}$ & $\begin{array}{l}\text { Fractures at } \\
\text { vertebral } \\
\text { column, } \\
\text { femur, wrist } \\
\text { and humerus. } \\
\text { Low-energy or } \\
\text { high energy } \\
\text { not reported. } \\
\\
\text { All fractures } \\
\text { except for } \\
\text { those occuring } \\
\text { at the face, } \\
\text { skull or digits }\end{array}$ & $\begin{array}{l}\text { CD4, viral } \\
\text { load, history } \\
\text { of an AIDS- } \\
\text { defining } \\
\text { illness, } \\
\text { current ART } \\
\text { use }\end{array}$ & $\begin{array}{l}\text { Age, race, BMI, } \\
\text { current smoking, } \\
\text { alcohol use }\end{array}$ & $\begin{array}{l}\text { Hypertension, } \\
\text { diabetes, } \\
\text { estimated } \\
\text { glomerular } \\
\text { filtration rate } \\
\text { (eGFR) }\end{array}$ & $\begin{array}{l}\text { Poisson } \\
\text { regression } \\
\text { model }\end{array}$ & $\begin{array}{l}\text { 0.95 [0.62-1.44] } \\
\text { Author } \\
\text { conclusion: } \\
\text { No association } \\
\\
1.11 \text { [0.86-1.45] } \\
\text { Author } \\
\text { conclusion: } \\
\text { No association }\end{array}$ & $\begin{array}{l}\text { 1.25 [0.94-1.67] } \\
\text { Author } \\
\text { conclusion: } \\
\text { No association } \\
\\
1.14 \text { [0.95-1.38] } \\
\text { Author } \\
\text { conclusion: } \\
\text { No association }\end{array}$ & Not analysed \\
\hline $\begin{array}{l}\text { Garcia et al. } \\
{[25]} \\
\text { Am J Ther }\end{array}$ & $\begin{array}{l}\text { European } \\
\text { pharmacovigil } \\
\text { database } \\
\text { between } \\
2001 \text { and } \\
\text { November } \\
10,2016\end{array}$ & $\begin{array}{l}181 \text { with } \\
\text { TDF } \\
\text { exposure } \\
\text { versus } \\
67932 \\
\text { without } \\
\text { TDF } \\
\text { exposure } \\
\text { out of } \\
4,776,472 \\
\text { reports } \\
13 \text { with } \\
\text { TDF }\end{array}$ & $\begin{array}{l}\text { TDF presence } \\
\text { (no/yes) }\end{array}$ & $\begin{array}{l}\text { All fractures } \\
\text { Osteoporotic } \\
\text { fractures }\end{array}$ & & & & $\begin{array}{l}\text { Proportional } \\
\text { reporting } \\
\text { ratios (PRR) }\end{array}$ & $\begin{array}{l}\text { 1.11 [0.96-1.28] } \\
\text { Author } \\
\text { conclusion: } \\
\text { No } \\
\text { disproportionality } \\
\\
17.2 \text { (9.9-30.0) } \\
\text { Author } \\
\text { conclusion: } \\
\text { disproportionality } \\
\text { was observed } \\
\text { for osteoporotic } \\
\text { fractures }\end{array}$ & $0.54[0.45-0.64]$ & \\
\hline
\end{tabular}




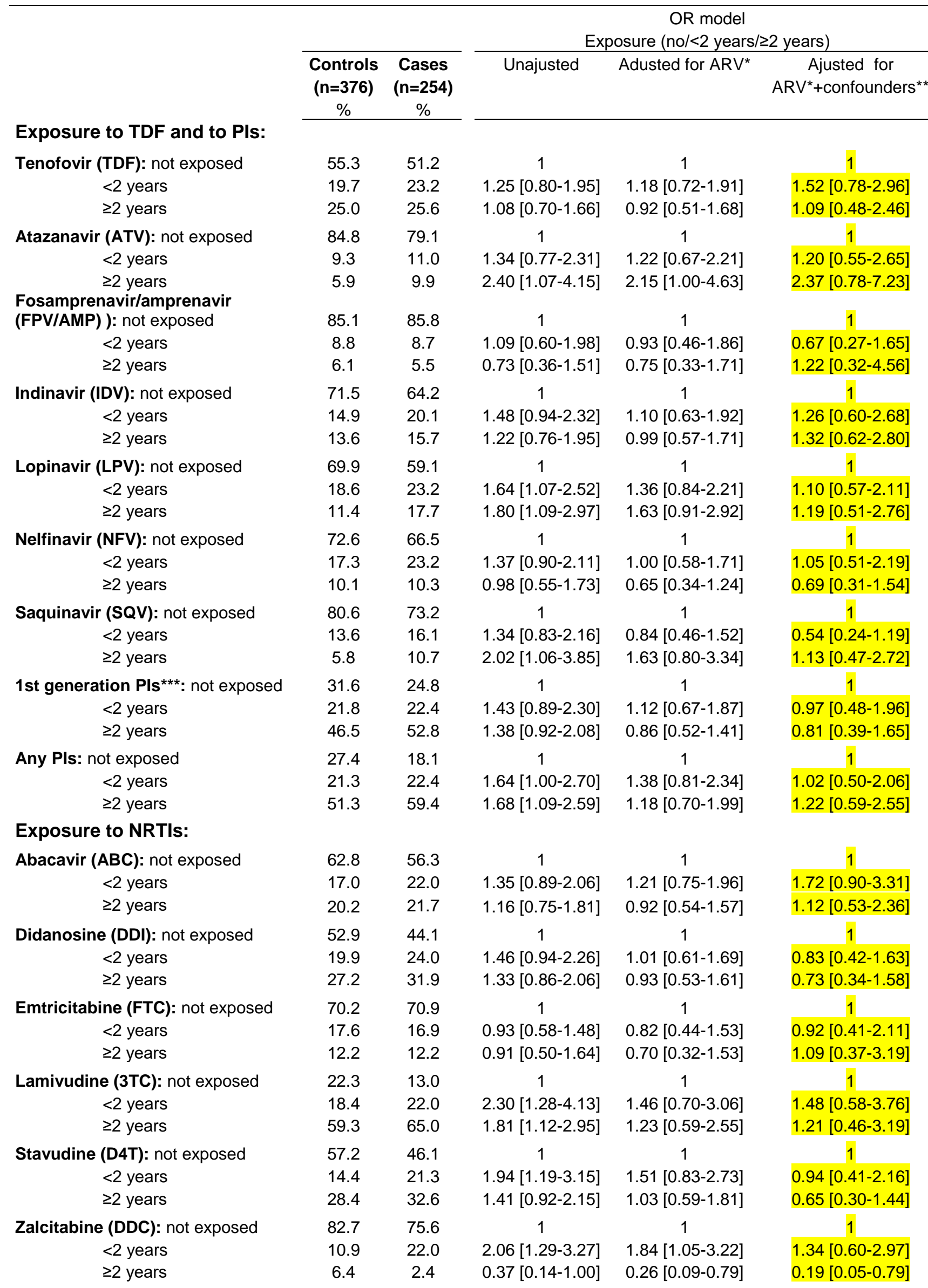




\begin{tabular}{|c|c|c|c|c|c|}
\hline & \multirow[b]{2}{*}{$\begin{array}{c}\text { Controls } \\
(n=376) \\
\%\end{array}$} & \multirow[b]{2}{*}{$\begin{array}{c}\text { Cases } \\
(n=254) \\
\%\end{array}$} & \multicolumn{3}{|c|}{$\begin{array}{c}\text { OR model } \\
\text { Exposure (no/<2 years } / \geq 2 \text { years })\end{array}$} \\
\hline & & & Unajusted & Adusted for ARV* & $\begin{array}{c}\text { Ajusted for } \\
\text { ARV }^{*}+\text { confounders }\end{array}$ \\
\hline Zidovudine (ZDV): not exposed & 28.5 & 20.1 & 1 & 1 & 1 \\
\hline$<2$ years & 22.9 & 22.8 & $1.50[0.90-2.49]$ & $0.85[0.43-1.68]$ & $0.90[0.37-2.21]$ \\
\hline$\geq 2$ years & 48.7 & 57.1 & $1.62[1.04-2.51]$ & $1.11[0.59-2.09]$ & $1.04[0.46-2.38]$ \\
\hline \multicolumn{6}{|l|}{ Exposure to NNRTIs: } \\
\hline Efavirenz (EFV): not exposed & 66.2 & 62.6 & 1 & 1 & 1 \\
\hline$<2$ years & 17.8 & 23.2 & $1.41[0.93-2.12]$ & $1.23[0.78-1.96]$ & $1.11[0.60-2.07]$ \\
\hline$\geq 2$ years & 16.0 & 14.2 & 0.89 [0.55-1.43] & $0.96[0.55-1.67]$ & $0.64[0.30-1.36]$ \\
\hline Nevirapine (NVP): not exposed & 79.3 & 66.5 & 1 & 1 & 1 \\
\hline$<2$ years & 11.4 & 20.5 & $2.23[1.40-3.55]$ & $1.88[1.12-3.18]$ & 1.98 [0.99-3.99] \\
\hline$\geq 2$ years & 9.3 & 13.0 & $1.58[0.93-2.69]$ & $1.45[0.79-2.66]$ & $1.14[0.49-2.61]$ \\
\hline
\end{tabular}

\section{* ARV exposure coding in model 3}

**Potential confounders: transmission group (MSM/injecting drug users/others), geographic origin (Sub-Sahara/others), AIDS-stage (yes/no), BMI ([18.5-25.0]/<18.5/>25.0), smoking status (no/past/current), alcohol consumption ( $\leq$ 2glasses/day/>2glasses/day), exposure to systemic glucocorticoids (no/yes), period of enrolment ( $\leq 1996 / 1997-$ $2001 / \geq 2002$ ).

***All Pls except darunavir and atazanavir 